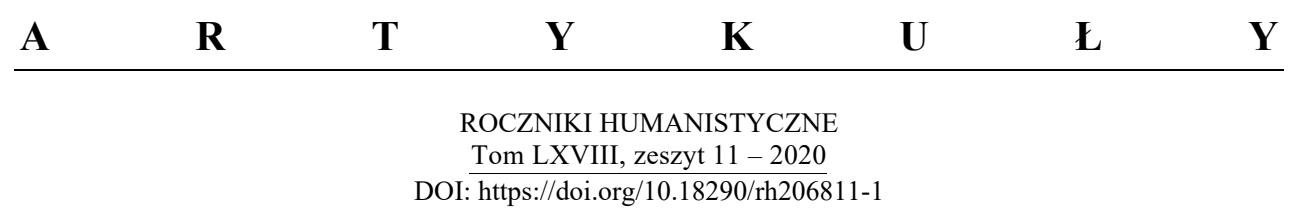

PATRYCJA ANTOSZEK

\title{
AFFECTIVE TRANSMISSION AND HAUNTED LANDSCAPE IN JESMYN WARD'S SING, UNBURIED, SING
}

\begin{abstract}
A bstract. The essay discusses Jesmyn Ward's novel Sing, Unburied, Sing (2017) through Nicolas Abraham's and Maria Torok's concept of "transgenerational phantom" and Teresa Brennan's theory of the transmission of affect. While the novel focuses on poor blacks in the contemporary American South, and, therefore, on the experience of those marginalized and excluded from official discourse, the narrative seems to transgress racial, social, and generational boundaries to address the human predicament in ways that are both visceral and poetic, disturbing and magical. By employing the trope of haunting to talk about racial oppression, the author combines past and present to demonstrate how slavery and racism continue to take their toll, producing more individual and communal traumas. The essay argues that in Sing, Unburied, Sing Ward not only deconstructs such dominant Western categories as past and present, black and white, male and female, or life and death, but also indicates a way of dealing with and communicating traumatic realities that goes beyond the Symbolic patterns of making sense of the world.
\end{abstract}

Keywords: affect; haunting; transgenerational phantom; slavery; trauma.

In Sing, Unburied, Sing (2017) Jesmyn Ward tells a half-lyrical, half-political tale of modern-day Mississippi haunted by its horrific past and that past's ongoing legacy. As all her fiction, including the debut novel Where the Line Bleeds (2008) and Salvage the Bones (2011), Sing is set in the fictional town of Bois Sauvage (Savage Woods), modeled on the small, Gulf Coast town of DeLisle, where the author grew up. While Ward's novels focus on the poor black community in the contemporary American South, and, therefore, on the experience of those marginalized and excluded from the official discourse, her

Patrycja Antoszek, PhD, The John Paul II Catholic University of Lublin, Institute of Literary Studies, Department of American Literature and Culture; address for correspondence: Al. Racławickie 14, 20-950 Lublin, Poland; e-mail: patrycja.antoszek@kul.pl; ORCID: https://orcid.org/00000002-9784-6269. 
writing seems to transgress racial, social, and generational boundaries to address the human predicament in ways both visceral and poetic, disturbing and magical. Ward, who openly admits her indebtedness to Toni Morrison, and especially the novel Beloved, ${ }^{1}$ conjures up her own ghosts to demonstrate "how inextricably interwoven the past is in the present, how heavily that past bears on the future" (Ward, The Fire 19). While Morrison's Beloved embodies all the "disremembered and unaccounted for" (275) in the history of American slavery, Ward's ghosts remind us that, even though slavery is officially over, racial politics takes its toll in individual and communal traumas that refuse to be forgotten. Focusing on the present, Ward explores an African American reality in which the traumas of slavery and Jim Crow, multiplied by poverty, private wounds, and individual loss, linger in every nook and cranny of the geographical and emotional landscape. Above all, Ward's fiction is characterized by her profound understanding of the contemporary South coupled with a "willingness to bring secrets and despair and hope and all those other messy human emotions to life" (Ward and Taylor, Literary Voice 267). Like Morrison, she also struggles with how to tell the story that is too painful to talk about, "how to rip that veil drawn over "proceedings too terrible to relate"" (Morrison, "The Site" 91). In Sing, Unburied, Sing, Ward paints an affective picture of the American South, while offering a powerful counternarrative to the official histories of racial violence.

The author's literary influences are easily recognizable: apart from Morrison, whose emotional intensity and spectral imagination are also Ward's trademarks, she is heavily indebted to William Faulkner's As I Lay Dying, which was a major point of reference also in Salvage the Bones. ${ }^{2}$ Sing focuses on a poor southern African American family-Jojo, Kayla, and their mother Leoniewho travel to the state penitentiary to bring home the children's father, incarcerated for a drug-related crime. As in Faulkner, the story centres on a difficult pilgrimage and complicated family relationships, alludes to The Odyssey, and gives voice to the dead. However, whereas in Faulkner this voice belongs to the mother, who tells her story before the family buries her in Jefferson, in Ward's novel it is the dead-undead child Richie, whose ghost appears in Leonie's car and insists his story be told. Like Addie Bundren in As I Lay Dying, Richie's narrator-ghost is a catalyst for the characters' confrontations with painful memories and uncomfortable truths. As in Faulker's classic work too, Ward's

\footnotetext{
${ }^{1}$ See, for example, Ward, "I Was Wandering." Accessed 1 Dec. 2020.

${ }^{2}$ For a detailed discussion of the similarities between these two texts, see Moynihan, "From Disposability to Recycling."
} 
novel expands individual narratives into a haunting tale of the American South by foregrounding that which Americans prefer not to see: poverty, historical and individual trauma, family violence, and death. Moreover, by addressing issues of slavery and race, the novel disrupts, in true gothic fashion, the myths of innocence, purity, and equality that lie at the heart of American national narratives (cf. Goddu 10).

The fact that Sing, Unburied, Sing draws heavily on Morrison and Faulkner has more than just literary significance. Combining historical traumas of African American slaves with social and economic conditions of the poor in the South, Ward's novel offers an expansive view of a region fraught with tragedies and conflicts that go beyond the categories of history and race. While these are undoubtedly present in the region's social and cultural landscape, Ward complicates the picture by exploring the uncanny interrelatedness of past and present, the co-mingling of black and white histories, and the after-effects of traumas that weigh heavily on both blacks and whites. The author's interest in the politics of race and racial mixture is not surprising considering her own family history. Yet it testifies to a more comprehensive understanding of Southern complexities. ${ }^{3}$ In what follows, I will argue that in Sing, Unburied, Sing Ward not only deconstructs such dominant Western paradigms as past/present, black/white, male/female, and life/death, but also provides a means for addressing and communicating traumatic realities that transcend official Symbolic forms of making sense of the world.

The novel's major protagonist, Jojo, is a mixed-race boy who has just turned thirteen, though like Ward's other characters, seems mature and selfsufficient for his age. As his mother, Leonie, is overcome by grief after her brother's death, and his white father, Michael, is serving time in prison, Jojo cares for his three-year-old sister Kayla. Emotionally neglected by both parents, whose obsessive love for each other makes them unavailable to anyone else, the boy transfers his filial affection to his grandparents, whom he calls Mam and Pop. As the story opens, Jojo is following his Pop to the shed to help him kill a goat they will eat for his birthday. The boy tries to act and move

\footnotetext{
${ }^{3}$ In her essay "Cracking the Code," Ward talks about her complicated family history, including racial violence and mixed roots: "it was discomfiting to find that my ancestry was 40 percent European - a mixture of British, Irish, French, German, Scandinavian, Iberian, Italian, and Ashkenazi-32 percent sub-Saharan African, a quarter Native American, and less than 1 percent North African.... I looked into the mirror and didn't know how to understand myself. I tried to understand my heritage through my features, to assign each one a place, but I couldn't" (146-47). In her memoir, Men We Reaped (2013), the author describes her painful experiences of growing up in Mississippi marked by the legacy of slavery, racial hatred, and individual loss, which included her own brother.
} 
like a grown-up man, "to look like this is normal and boring so Pop will think I've earned these thirteen years... I want Pop to know I can get bloody" (1).

At the same time, Jojo behaves like a surrogate mother toward his sisterhe brings her bottle at night, sleeps with her and holds her tight "as if he thinks he could curl around her, make his skeleton and flesh into a building to protect her from the adults, from the great reach of the sky, the vast expanse of the grass-ridden earth, shallow with graves" (133). As both black and white, child and adult, male and female, Jojo not only slips out of established categories, but escapes the boundaries of his self to become more open to other selves and therefore more affectively influenced by others, human and non-human. In other words, rather than being self-contained and separate from the world, Jojo's subjectivity, with its porous and permeable borders, is susceptible to affective influences and transmissions. As an example of what Teresa Brennan has called "a feminine being," Jojo is both influenced by and carries the negative affects and emotions for the other. ${ }^{4}$ The phenomenon, which Brennan refers to as "the transmission of affect," implies that "the emotions or affects of one person, and the enhancing or depressing energies these affects entail, can enter into another" (3).

According to Brennan, the transmission of affect is "a process that is social in origin but biological and physical in effect" (3). While the term "affect" comes from the Latin affectus, meaning "passion" or "emotion," affect is deeply rooted in the physicality of the body: it is "the name we give to those forces-visceral forces beneath, alongside, or generally other than conscious knowing, vital forces existing beyond emotion" (Seigworth and Gregg 1). As Gregory J. Seigworth and Melissa Gregg further suggest, affect "is found in those intensities that pass body to body (human, non-human, part-body, and otherwise) in those resonances that circulate about, between, and sometimes stick to bodies and worlds, and in the very passages or variations between these intensities and resonances themselves" (1). In Ward's novel, Jojo experiences his "open-ended in-between-ness" through intensities of feeling that manifest themselves in violent bodily reactions, but also result in his ability to see and communicate with ghosts.

The importance of the physical/physiological for expressing difficult emotions is clear at the outset of the novel, when Jojo confesses: "I like to think I know what death is. I like to think that it's something I could look at straight" (1).

\footnotetext{
${ }^{4}$ As Brennan makes clear, the term "feminine beings" can apply not only to women, but also to children, non-human beings, or those racially marked as "other" (14-15). See also Atkinson, The Poetics 12.
} 
Despite his youth, death is not an abstraction - as he accompanies Pop in a bloody killing of a goat, inside the house, Mam has been quietly dying of cancer. Trying to prove his manhood, to show his grandfather that he is "old enough to look at death like a man should" (5), the boy watches the slaughtering scene:

Pop slits. The goat makes a sound of surprise, a bleat swallowed by a gurgle, and then there's blood and mud everywhere. The goat's legs go rubbery and loose, and Pop isn't struggling anymore. All at once, he stands up and ties a rope around the goat's ankles, lifting the body to a hook hanging from the rafters. That eye: still wet. Looking at me like I was the one who cut its neck, like I was the one bleeding it out, turning its whole face red with blood. (4)

The visceral immediacy of this scene brings about a confrontation with death in its purely physical, bodily aspect: as the goat is turned inside out, its skin peeled off, there is "the smell of death, the rot coming from something just alive, something hot with blood and life" (6). Seeing the body without skin, that is without its natural boundaries, with the innards out, straddling life and death is, according to Julia Kristeva, approaching the border of nonexistence, "the place where meaning collapses" (2). In Kristevan terms, this is a confrontation with the abject: with that for which there is no category, a signifier without a signified. Jojo's desire "to know" death cannot be fulfilled since death is always already beyond cognition or signification. As that which "disturbs identity, system, order" (Kristeva, Powers 4), death cannot be known but can only be felt, or experienced through the body. As Kristeva demonstrates, confronting that which we $a b$-ject, or expel in order to exist, that which threatens the integrity of the self, which brings one to "the edge of non-existence," usually provokes a physical reaction: spasms in the stomach, nausea and vomiting (Kristeva, Powers 2-4). In order to protect himself, "to cut off that stink of death.... the soft eye of the goat," Jojo has to respond through a bodily reaction: "I can't hold myself still and watch no more, then I'm out the door of the shed and I'm throwing up in the grass outside" (6).

The affective intensity of the opening scene, in which the desire for meaning is rendered impossible and replaced with a feeling of revulsion as the only possible response to the limits of representation, sets the novel's tone and prepares readers for a discourse based on non-verbal, pre-Symbolic forms of expression. In psychoanalytic terms, the Symbolic register is "that plane where meaning resides: discourse, narrative, communicative systems" (Kerner 184), while the Semiotic, according to Kristeva, is the space in language where the inexpressible maternal, pre-Oedipal drives and energies exist. "These two 
modalities," she contends, "are inseparable within the signifying process that constitutes language, and the dialectic between them determines the type of discourse (narrative, metalanguage, theory, poetry, etc.) involved.... On the other hand, there are nonverbal signifying systems that are constructed exclusively on the basis of the semiotic (music, for example)" (Revolution 24). In her attempt to tell the story of trauma, racism, violence, and death, Ward faces a challenge of speaking the unspeakable, of telling a story that cannot be told and must be told at the same time. By beginning her narrative with the abject and, thus, by referring to the bodily, visceral forces ordinarily repressed, Ward opens her narrative to the Semiotic modes of articulation and prepares the ground for the exploration of that which typically escapes the boundaries of traditional signifying systems.

One of the author's strategies to address an unspeakable history is, as in Morrison's Beloved, the use of ghosts. Both visible and invisible, ghosts reside in the in-between and "stand in defiance of the binary oppositions (life or death, inside or outside as well as present or past) that constitute our symbolic system" (Berthin 3). As Kathleen Brogan observes, ghosts appear in the folklore of almost every culture and typically function as "useful literary metaphors in the larger process of ethnic invention and revision" (163). What is more, the ghost can serve "as an emblem of historical loss as well as a vehicle of historical recovery":

The ghost gives body to memory, while reminding us that rememberring is not a simple or even a safe act. Like the partially obliterated records that appear in contemporary haunted literature - the family papers mildewed and faded, stories left without endings or explanations, crucial words that resist translation - the ghost's elusiveness conveys a past not easily accessible. (Brogan 163-64)

In this sense, Brogan explains, ghosts not only provide access to uncomfortable historical facts, but also constitute "particularly rich metaphors for the complexities of cultural transmissions" (164). Haunting and ghosts were probably most widely discussed by Jacques Derrida in Specters of Marx (1994), which enlarges the meaning of ghosts to include their ethical and political dimension, as well as their persistence in the present. For Derrida, "it is imperative to address the ghost figure in order to respect and bear responsibility towards those from the past and those from the future who will suffer the most terrible oppressions and violence" (Heholt 9). Haunting, then, should be seen in terms of its significance for the present: we should learn to live with ghosts and "this 
being-with specters would also be, not only but also, a politics of memory, of inheritance, and of generations" (Derrida xviii).

Undoubtedly, Ward's employment of ghosts in Sing, Unburied, Sing functions to show the continuity of past traumas in the present, as well as the need to find a language for communicating with that past. Richie, who appears to Jojo on the way to Parchman prison, is the ghost of a boy he knows from Pop's stories. When they were still teenagers, Richie and Pop served their time in Parchman - the former for stealing food for his family, the latter for "hiding a fugitive" - that is, his brother-who earlier got into a fight with a white man. Pop often tells Jojo about the horrors of being a prisoner, which in Parchman was much like being a slave, but he never tells the whole story: "Whenever Pop done told me his and Richie's story, he talked in circles. Telling me the beginning over and over again. Telling me the middle over and over again. Circling the end like a big black buzzard angles around dead animals, possums or armadillos or wild pigs or hit deer, bloating and turning sour in the Mississippi heat" (248). What Pop finds impossible to put into words is that he had to kill Richie and let his body be torn by dogs to save him from lynching. Never properly mourned or buried, Richie returns as a ghostly apparition not to Pop himself, but to Jojo, who is not even aware of his grandfather's psychic wound but takes upon himself his grief. In this sense, Richie becomes what Nicolas Abraham and Maria Torok refer to as "the phantom"-a phenomenon resulting from the transgenerational transmission of an undisclosed secret. According to Abraham and Torok, "some people unwittingly inherit the secret psychic substance of the ancestors' lives," and, therefore, unlike in Freudian theory, their ghostly visions or "symptoms do not spring from the individual's own life experiences but from someone else's psychic conflicts, traumas, or secrets" (166). Moreover, the phenomenon may result from "a direct empathy with the unconscious or the rejected psychic matter of a parental object" (181; italics in original). The phantom, then, represents how unspeakable and unspoken trauma(s) of previous generations haunt and disturb human lives in later ones.

Discussing the nature of the phantom developed by Abraham and Torok against Derrida's concept of the ghost, Colin Davis points to the fact that none of them has anything to do with the belief in the supernatural. While for Abraham and Torok "what haunts are not the dead, but the gaps left within us by the secrets of others" (171), in Derrida's hauntology "[a] specter is a deconstructive figure hovering between life and death, presence and absence, and making established certainties vacillate. It does not belong to the order of knowledge" (Davis 376). The ghost, whose "non-present presence makes it 
inaccessible to symbolization" (Parkin-Gounelas 137-38), embodies the disruption of the Symbolic. In other words, regardless of how we approach a literary ghost, we realize that not only does it exist beyond the accepted systems of signification, but, also, its function is primarily to communicate a story which cannot be articulated by means of conventional linguistic structures. In The Shell and the Kernel, Abraham and Torok speak of "a 'kernel' of absence, an 'unthought,' a 'non-presence' at the core of discourse" and draw attention to "the limits of the communicable in language" (Berthin 6-7). As Christine Berthin asserts, " $\mathrm{t}] \mathrm{h}$ here is always a remainder in signification, something that remains 'undead,' neither alive as a thing outside language, nor transformed into a sign in the process of symbolization, something that our structures, our linguistic and symbolic structures cannot assimilate" (6).

Just as the Kristevan Semiotic can never be integrated into official language, trauma belongs to that category of experiences which cannot be effectively conveyed through words. According to Meera Atkinson,

[w] hen it comes to trauma, truth is not only the thing you must not say, but also the thing you cannot say. The thing you cannot say, as such, may best be expressed creatively, imaginatively, poetically, and affectively. Words, however malleable, can never completely convey the visceral surge of terror or profound shame, or the subjective splitting at the root of trauma, and yet, when set loose in linguistic or structural experimentation they get closer to doing so than when confined in orthodox mores and routine strategies. (The Poetics 16)

Exploring the poetics of transgenerational trauma, Atkinson proves that dealing with an often-inaccessible traumatic event entails experiencing it through the body's affective reality. To talk about a traumatic past, Atkinson suggests, "our idea of language may need to be expanded to include language (as a system of signs and symbols) outside of language proper, such as affect" ("Channeling the Specter" 256). Affect, like the ghost, offers a different form of communication and "makes it possible to consider trauma beyond cognition and language, beyond the individual and the collective, and even beyond the human" (Atkinson, Traumatic Affect 15). Therefore, Atkinson posits, "embodied affect is what enables that quality of trauma that remains unknowable and outside language to be spectrally evoked within the haunted text" (Traumatic Affect 16).

In her narrative of grief, dying, and pain, Ward relies on phantoms and specters to communicate the haunting nature of traumatic experience and its persistence into the present. While the ghost of Richie embodies Pop's personal tragedy of having to murder a friend, locating his ordeals in Parchman 
prison, where racial violence and agricultural work make it a contemporary version of a Southern plantation, implies that, despite American myths of equality and freedom, slavery and racism are an inextricable part of American life. As Richie puts it, "Parchman was past, present, and future all at once" (186). The phantom of Given, Leonie's brother, shot by a white man out of jealousy and anger, appears to his sister each time she is on drugs: "the hollow figment" of the "weird corner of [her] brain" (150). Since Given was a tragic victim of racial hatred, his specter proves the continuity and pervasiveness of racist ideologies: he too is "[p]ulling all the weight of history behind him" (265). The idea that collective memory always coexists with individual losses returns at the end of Ward's novel, when an entire community of ghosts, wearing "rags and breeches, T-shirts and tignons, fedoras and hoodies" (283), unite past and present, proving that "we don't walk no straight lines. It's all happening at once. All of it. We all here at once" (236). Thus challenging the Western concept of time as linear, the narrative incorporates the nightmares of history into the present, suggesting indelible layers of memory embedded in the southern American landscape.

Although, like Morrison's Beloved, Sing, Unburied, Sing incorporates embodied ghosts to "rematerialize" African American history, the novel reimagines the idea of haunting by going beyond the categories of the individual and the human. While Richie looks "like he has a body, has skin and bones and muscle" (182), he can easily transform into an animal, moving up the tree "like a white snake" and joining a community of ghosts who "perch like birds, but look as people":

He undulates along the trunk, to the branches, where he rolls out along one, again in a recline. And the branches are full. They are full with ghosts, two or three, all the way up to the top, to the feathered leaves. There are women and men and boys and girls. Some of them near to babies. They crouch, looking at me. Black and brown and the closest near baby, smoke white. None of them reveal their deaths, but I see it in their eyes, their great black eyes. They perch like birds, but look as people. They speak with their eyes: He raped me and suffocated me until I died I put my hands up and he shot me eight times she locked me in the shed and starved me to death while I listened to my babies playing with her in the yard they came in my cell in the middle of the night and they hung me they found I could read and they dragged me out to the barn and gouged my eyes before they beat me still I was sick and he said I was an abomination and Jesus say suffer little children so let her go and he put me under the water and I couldn't breathe. (282-83) 
As the ghosts "speak with their eyes," the gaping mouths symbolize crimes both unspeakable and impossible to speak out. Their stories fuse into a continuous silent song. Consequently, while the novel gives voice to the oppressed who had long been erased from official cultural memory, it also shows the impossibility of articulating their traumas by ordinary systems of representtation. Their mute song mixed with "the airy rush" of the wind represents what Morrison believes is "not a story to pass on," that is "a history that can never be completely spoken or silenced" (Goddu 154). As the natural landscape fills with these human/non-human ghosts, the idea of the ghost, as well as the idea of the landscape, are expanded to include a multiplicity of meanings and experiences. In Ward's novel, haunting not only breaks the binaries of present/absent, alive/dead, here/there, but also those of human/non-human and nature/culture, suggesting a fluid notion of landscape that is continually in flux. As Ruth Heholt argues, "[p]laces are always marked by what has gone before, by the people who populated and shaped" them, by the conception of landscape, and by haunting, which can only be "experienced by and through the body" (2-4).

By relying on the language of the physical and physiological, Ward broadens her discourse to include pre-linguistic modes of communication, which form the Semiotic underside of language proper. One form of this other language/language of the Other is the incorporation of the abject and the visceral experience as an affective response to that which remains beyond representation. As an intensity that passes between bodies, affect manifests itself through bodily symptoms - "persistent proof of a body's never less than ongoing immersion in and among the world's obstinacies and rhythms" (Seigworth and Gregg 1). Ward's narrative records multiple instances of vomiting (Jojo's, Kayla's, Leonie's) as a bodily reaction to the inability to assimilate and process the overwhelming past and unbearable present. At the same time, the "smell of death," which surfaces in the novel's opening scene, continually haunts the protagonists and reader alike - the smell of Kayla's prolonged vomiting in the car, of Richie's blood on Pop's hands, of Mam's dying, or of "horror and grief" in Leonie's words, "all of it distilled to one pungent syllable" (274).

The discourse of feeling that dominates Sing, Unburied, Sing becomes particularly prominent in the novel's closing sections, when the affective tensions accumulate and the boundaries between the Symbolic and Semiotic seem to dissolve. As the voices of the living, the dead, and the animals merge, "Richie's yelp slides into a humming. He's singing to Casper [a dog], and there are words in it but I can't understand them, like language flipped inside out. A skinned animal: an inverted pelt. I can't help it. I gulp against the 
feeling I want to throw up all the food that I ever ate" (237). Overtly alluding to the opening scene of killing and skinning the goat, the fragment exposes the possibility of and the necessity to rely on non-verbal, pre-Symbolic forms of discourse to address that which language cannot grasp. In the novel's final scene, Kayla, who is still a child and therefore not yet fully incorporated into the realm of language and culture, proves that it is only with the use of the Semiotic modes of articulation that one is able to communicate with ghosts and address the unspeakable aspects of history and culture:

"Go home," she says.

The ghosts shudder, but they do not leave. They sway with open mouths again.... So Kayla begins to sing, a song of mismatched, half-garbled words, nothing that I can understand. Only the melody, which is low but as loud as the swish and sway of the trees, that cuts their whispering but twines with it at the same time. And the ghosts open their mouths wider and their faces fold at the edges so they look like they're crying, but they can't. And Kayla sings louder. She waves her hand in the air as she sings, and I know it, know the movement, know it's how Leonie rubbed my back, rubbed Kayla's back, when we were frightened of the world. Kayla sings, and the multitude of ghosts lean forward, nodding. They smile with something like relief, something like remembrance, something like ease.... Kayla hums over my shoulder, says "Shhh" like I am the baby and she is the big brother, says "Shhh" like she remembers the sound of the water in Leonie's womb, the sound of all water, and now she sings it.

Home, they say. Home. (284-85)

As Kayla's memory of intrauterine existence and the language of the maternal mix with the sound of trees and the silence of ghosts, her song, like "[p]re-verbal communicative exchanges between Jojo, animals, and ghostly figures reincarnated in animal forms collapse the artificial boundaries of time, space, and species, and relocate the setting in an ancient, primal condition" (Choi 444).

In conclusion, Sing, Unburied, Sing is, to a large extent, a story about historical haunting and, like other ghost narratives, gives voice to those oppressed and silenced by official history. Ward, like Toni Morrison, Toni Cade Bambara, or Gloria Naylor before her, uses the trope of haunting to re-vision the idea of African American history, memory, and trauma. ${ }^{5}$ However, while signifying against official history, Ward's novel relies on ghosts and haunting to interrogate the dominant discourse and offer new forms of confronting and understanding traumatic history. "Being haunted," Avery Gordon suggests, "draws us affectively, sometimes against our will and always a bit magically,

\footnotetext{
${ }^{5}$ For an interesting discussion of the meaning of ghosts and haunting in African American texts, see for example, Chassot, Ghosts of the African Diaspora.
} 
into the structure of feeling of a reality we come to experience, not as cold knowledge, but as a transformative recognition" (8). When words fail, one way of approaching uncomfortable truths seems to be Ward's "language flipped inside out," that is a signifying system constructed on the basis of the Semiotic. As Heholt points out, "[a] haunting, an encounter with a ghost, is a dialogue of affect" (7), and Ward's narrative, with its visceral poetics, demonstrates how affect works to merge the Symbolic and Semiotic modalities within the signifying process. At the same time, relying on forms of communication repressed in official discourse, Ward's haunting tale draws us nearer to the experience of the fragility of human constructs and the reality of affective forces.

\section{WORKS CITED}

Abraham, Nicholas, and Maria Torok. The Shell and the Kernel: Renewals of Psychoanalysis, edited by Nicholas T. Rand, vol. 1, University of Chicago P, 1994.

Atkinson, Meera. "Channeling the Specter and Translating Phantoms: Hauntology and the Spooked Text." Traumatic Affect, edited by Meera Atkinson and Michael Richardson, Cambridge Scholars Publishing, 2013, pp. 247-70.

Atkinson, Meera. The Poetics of Transgenerational Trauma. Bloomsbury Academic, 2017.

Atkinson, Meera, and Michael Richardson. "Introduction: At the Nexus." Traumatic Affect, edited by Meera Atkinson and Michael Richardson, Cambridge Scholars Publishing, 2013, pp. 1-19.

Berthin, Christine. Gothic Hauntings: Melancholy Crypts and Textual Ghosts. Palgrave Macmillan, 2010.

Brennan, Teresa. The Transmission of Affect. Cornell UP, 2004.

Brogan, Kathleen. "American Stories of Cultural Haunting: Tales of Heirs and Ethnographers." College English, vol. 57, no. 2, 1995, pp. 149-65, www.jstor.org/stable/378807. Accessed 1 Dec. 2020.

Chassot, Joanne. Ghosts of the African Diaspora: Re-Visioning History, Memory, and Identity. Dartmouth College P, 2018.

Choi, Sodam. "The Haunted Black South and the Alternative Oceanic Space: Jesmyn Ward's Sing, Unburied, Sing." English Language and Literature, vol. 64, no. 3, 2018, pp. 433-51.

Davis, Colin. "Hauntology, Spectres and Phantoms." French Studies, vol. 59, no. 3, 2005, pp. 373-79.

Derrida, Jacques. Specters of Marx. 1994. Routledge, 2006.

Goddu, Teresa A. Gothic America: Narrative, History, and Nation. Columbia UP, 1997.

Gordon, Avery F. Ghostly Matters: Haunting and the Sociological Imagination. U of Minnesota P, 1997.

Heholt, Ruth. Introduction. Haunted Landscapes: Super-Nature and the Environment, edited by Ruth Heholt and Niamh Downing, Rowman and Littlefield, 2016, pp. 1-20.

Kerner, Aaron. "Gojira's Bones: The Monster as a Vessel of Affective Energy." Traumatic Affect, edited by Meera Atkinson and Michael Richardson, Cambridge Scholars Publishing, 2013, pp. 172-92.

Kristeva, Julia. Powers of Horror. An Essay on Abjection, translated by Leon S. Roudiez, Columbia UP, 1982. 
Kristeva, Julia. Revolution in Poetic Language, edited by Margaret Waller, Columbia UP, 1984.

Morrison, Toni. Beloved. Alfred A. Knopf, 1998.

Morrison, Toni. "The Site of Memory." Inventing the Truth: The Art and Craft of Memoir, edited by William Zinsser, Houghton Mifflin, 1995, pp. 83-102.

Moynihan, Sinead. "From Disposability to Recycling: William Faulkner and the New Politics of Rewriting in Jesmyn Ward's Salvage the Bones." Studies in the Novel, vol. 47, no. 4, 2015, pp. 550-67.

Parkin-Gounelas, Ruth. "Anachrony and Anatopia: Spectres of Marx, Derrida and Gothic Fiction." Ghosts: Deconstruction, Psychoanalysis, History, edited by Peter Buse and Andrew Scott, Macmillan Press, 1999, pp. 127-43.

Seigworth, Gregory J., and Melissa Gregg. "An Inventory of Shimmers." The Affect Theory Reader, edited by Melissa Gregg and Gregory J. Seigworth, Duke UP, 2010, pp. 1-25.

Ward, Jesmyn. "Cracking the Code." The Fire This Time: A New Generation Speaks about Race, edited by Jesmyn Ward, E-book, Scribner, 2016, pp. 139-49.

Ward, Jesmyn. Introduction. The Fire This Time: A New Generation Speaks about Race, edited by Jesmyn Ward, E-book, Scribner, 2016, pp. 10-24.

Ward, Jesmyn. Sing, Unburied, Sing. Bloomsbury, 2017.

Ward, Jesmyn, and Danille K. Taylor. "Literary Voice of the Dirty South: An Interview with Jesmyn Ward." CLA Journal, vol. 60, no. 2, "Decolonizing the University: A Battle for the African Mind" (Dec. 2016), pp. 266-68, www.jstor.org/stable/10.2307/26355922. Accessed 1 Dec. 2020.

TRANSMISJA AFEKTU I WIDMA PRZESZŁOŚCI

W POWIEŚCI JESMYN WARD ŚPIEWAJCIE, Z PROCHÓW, ŚPIEWAJCIE

\section{Streszczenie}

Przedmiotem artykułu jest analiza powieści Jesmyn Ward pt. Śpiewajcie, z prochów, śpiewajcie (2017) w świetle pojęcia „międzypokoleniowej transmisji fantomu” Nicolasa Abrahama i Marii Torok oraz teorii transmisji afektu Teresy Brennan. Posługując się motywem duchów, powieść Ward porusza temat przemocy na tle rasowym i łączy przeszłość z teraźniejszością dowodząc, że niewolnictwo i rasizm nadal zbierają żniwo w społeczeństwie amerykańskim, a ich efektem są wciąż nowe osobiste i społeczne traumy. Artykuł pokazuje, że w tej powieści Ward nie tylko dekonstruuje dominujące $\mathrm{w}$ zachodnim świecie kategorie, takie jak: przeszłość/teraźniejszość, czarny/biały, męski/kobiecy czy żywy/martwy, ale także wskazuje sposób radzenia sobie z traumą i komunikowania jej wychodzący poza symboliczne formy interpretacji rzeczywistości.

Słowa kluczowe: afekt; widmo; międzypokoleniowy fantom; niewolnictwo; trauma. 